\title{
СТАТЬИ
}

\section{Trophic Links Between Birds of Prey and Their Preys and Theirr Competitors in Wetlands During Nesting Period}

\section{АДАПТИВНЫЕ ОСОБЕННОСТИ КРУПНЫХ ХИЩНЫХ ПТИЦ К РАЗДЕЛЕНИЮ ТРОФИЧЕСКИХ НИШ В ЛЕСОБОЛОТНЫХ КОМПЛЕКСАХ В ГНЕЗДОВОЙ ПЕРИОД}

\author{
Ivanovsky V.V. (Masherov Vitebsk State University, Vitebsk, Belarus) \\ Ивановский В.В. (Витебский госуниверситет им. Машерова, Витебск, Беларусь)
}

\author{
Контакт: \\ Влачимир \\ Вачентинович \\ Ивановский \\ Касенра экологии \\ и охраны природы \\ УО «Витебский \\ государственный \\ университет имени \\ П.М. Машерова" \\ 210038, Беларусь, \\ Витебск, Московский \\ проспект, 33 \\ ivanovski.46@mail.ru
}

\section{Contact:}

Vladimir V. Ivanovsky

Masherov Vitebsk State

University

Moskovskiy ave., 33,

Vitebsk, 210038,

Belarus

ivanovski.46@mail.ru

\section{Резюме}

Статья посвяшена анамизу трофических связей крупных хишных птиц и изучению ацаптивных механизмов уменьшения межвидовой трофической конкуренции. В работе анамизируются ацаптивные механизмы, используемые хишными птицами мяя ослабления трофической конкуренции межАу собой в гнездовой период в лесоболотных комплексах в Северной Беларуси. В исследовании показано, что в этот период года реальной трофической конкуренции межАу хишными птицами не наблюдается, несмотря на перекрытие трофических ниш у некоторых видов более 0,6 единицы.

Киючевые слова: хишные птицы, трофическая конкуренция, пишевые ресурсы, механизмы разделения, лесоболотные комплексы, Северная Беларусь.

Поступияа в реАакцию: 21.11.2018 г. Принята к публикации: 15.03.2019 г.

\section{Abstract}

The article is dedicated to the analysis of trophic relations of large birds of prey and adaptive mechanisms they use to reduce interspecific trophic competition during the breeding period in wetlands in Northern Belarus. The study shows that during this period, no significant trophic competition is present between raptors despite the overlap of trophic niches in some species.

Keywords: birds of prey, competition, food niche overlap, trophic resources, mechanisms of partitioning, wetlands, Northern Belarus.

Received: 21/11/2018. Accepted: 15/03/2019.

DOI: $10.19074 / 1814-8654-2019-38-15-22$

\begin{abstract}
Актуальность исследуемой проблемы
Анализ конкурентных отношений в многовиАОвом сообшестве позвоночных хишников и их жертв является предметом исслеАования целого ряда зарубежных и некоторых отечественных групп учёных (Marti et al., 1993; Jedrzejewska, Jedrzejewski, 1998; Sidorovich, 2011; Ивановский и др., 2018). Тем не менее, в Аанной области биологии остаётся ряд нерешённых залач, как теоретического, так и практического характера. Обширный отряА хишных птиц, как часть этого еАиного сообщества, остаётся слабо изученным (Newton, 1976; 1979; Ивановский, 2012 и нр.).

Целью Аанного исследования является выявление ацаптационных реакций и механизмов ослабления тросической конкуренции межАу крупными хишными птицами.
\end{abstract}

\section{Материал и методика исследований \\ Материалы мяя анамиза собраны в пери- од с 1972 по 2017 годы. Всего в добыче}

\section{Introduction}

Analysis of predator-prey relationship in multispecies vertebrate communities is the subject of many studies (Marti et al., 1993; Jedrzejewska, Jedrzejewski, 1998; Sidorovich, 2011 ; Ivanovskiy et al., 2018). However, birds of prey are poorly studied in this concern (Newton, 1976; 1979; Ivanovskiy et al., 2012).

The purpose of this study is to identify adaptive reactions and mechanisms for reducing the trophic competition between large birds of prey.

\section{Methods}

Samples were collected between 1972 and 2017. A total of 2,672 specimens of prey $(100 \%)$ were identified in pellets and prey remains in nests and near the perches. For the analysis, we divided all prey species into 22 categories and calculated the percentage of each category in raptor's diet. To evaluate the rates of different prey catego- 


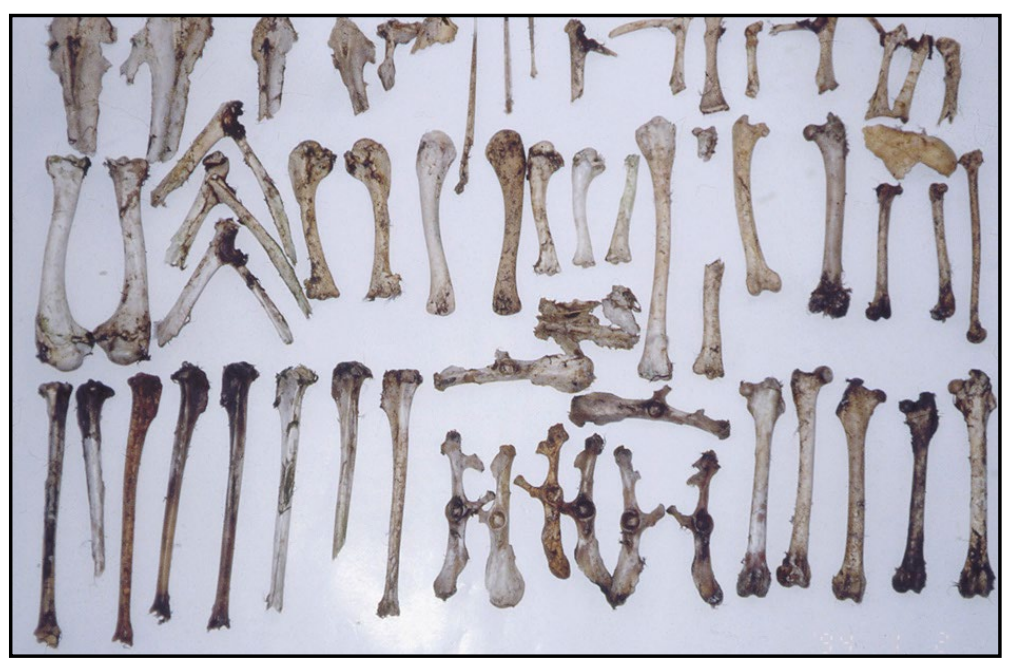

крупных хишных птиц определено 2672 экземпляра добычи.

Питание хишных птиц изучамось путём сбора остатков пиши и погадок на гнёздах и на территории гнездовых участков под присацами. Остатки собирамись 1-2 раза в сезон, а на контрольных гнёздах - раз в неделю. Остеологический материал опреАелялся путём сравнения с контрольной остеологической комекцией. Перья объектов питания определялись путём сравнения с перьями комекционных тушек зоологического музея Витебского университета имени П.М. Машерова, с учётом специаиьных рекомендаций (Brown, Ferguson, 1999; März, 1987). ИАентисрикацию остатков мелких млекопитаюших в пишевых пробах выполняли двумя методами: (1) по черепам, зубам и мругим частям скелета (Шепель, Маяков, 1986; Шепель, Шохрин, 1985; Pucek, 1981), (2) по особенностям микроскопической структуры Аесяти случайно взятых из погаяки волос (Teerink, 1991). Таксономическую приналежность земноводных определяли по костям с использованием специамьных киючей и атласов, рептилий - по костям и покровам, птиц - по костям и перьям (Böhme, 1977; März, 1972). Количество экземпляров животных определяли путём подсчёта всех непарных и парных (отдельно, левых и правых) костей скелета с учётом их размеров и степени свежести.

Процедура расчёта состава рациона была следуюшей. Обшее количество всех особей жертв, выявленных во всех пишевых пробах, было взято за 100\% при расчёте встречаемости разных кормовых категорий. Аия оценки соотношения в рационе разных кормовых объектов по потреблённой биомассе (\% ПБ) использовами стандартный поАХоА, закАючаюшийся в пересчёте встречаемости разных кормо-
Остеологический материаи из остатков Аобычи беркута (Aquila chrysaetos): верхний рял - тетеревиные птицы (Tetraonidae sp., нижний ряд - зайцы-беляки (Lepus timidus). Фото В.В. Ивановского.

Osteological material obtained from remains of prey of the Golden Eagle (Aquila chrysaetos): upper row Tetraonidae sp., lower row - Mountain Hares (Lepus timidus). Photo by V.V. Ivanovskiy.

ries in the diet according to consumed biomass (\% CB) we used a standard approach by multiplying the percentage of the given category by the average biomass of the prey species in the category (Sidorovich, 2011; 2014).

For every species, we calculated the width of the trophic niche according to Levin's formula (Krebs, 1990).

$$
\mathrm{B}=\left(\sum \mathrm{p}_{\mathrm{i}}^{2}\right)^{-1},
$$

where $p_{i}$ - is a percentage of a specific category of prey in the species diet.

A cluster analysis was conducted for the selection of guilds and visualization of results. The input data for the dendrograms were represented as a symmetric matrix of trophic niches overlapping calculated using the Morisita-Horn formula $\left(\mathrm{C}_{\mathrm{MH}}\right)$ (Krebs, 1999).

$$
\mathrm{C}_{\mathrm{MH}}=\frac{2 \sum_{i}^{n} \mathrm{p}_{\mathrm{ij}} \mathrm{p}_{\mathrm{ik}}}{\sum_{i}^{n} \mathrm{p}^{2}{ }_{\mathrm{ij}}+\sum_{i}^{n} \mathrm{p}^{2} \mathrm{ik}},
$$

where $p_{i j}$ and $p_{i k}$ - the percentage of the studied prey category in the diet of two species. The value of $\mathrm{C}_{\mathrm{MH}} \geq 0.6$ was considered ecologically and statistically significant.

For the cluster analysis and dendrograms we used Bray-Curtis and Jaccard metrics.

Statistical analysis was run in Microsoft Excel and PAST 3.06.

\section{Results}

The study was conducted in the Vitebsk Region of Belarus on the area of 40.1 thousand $\mathrm{km}^{2}$. Forests cover around $34 \%$ of the area, marshes - around $9 \%$. The area is dominated by 5 species of large birds of prey: Goshawk (Accipiter gentilis), Greater (Aquila [Clanga] clanga) and Lesser Spotted Eagles (Aquila [Clanga] pomarina), Golden Eagle (Aquila chrysaetos), Short-Toed Eagle (Circaetus gallicus) (Fedyushkin, Dolbik, 1967; Ivanovskiy, 2012).

A diet of these species is represented in table 1. 
вых категорий в потреблённую биомассу (\% ПБ) путём умножения встречаемости на среднюю массу жертвы. В том случае, если масса жертвы превышает суточную потребность в корме, то встречаемость умножами на суточную потребность в корме. Подробно вопрос расчёта потреблённой биомассы и средней массы жертв рассмотрен в монограсии В.Е. Сидоровича (Sidorovich, 2011) и в обзоре A.А. СиАорович (2014).

Аяя удобства расчётов, анаииза и вымеления гильдий было вылелено 22 категории пишевых ресурсов, процент содержания которых рассчитывался в питании каждого хишника. Также мля каждого вида хишной птицы рассчитываяась ширина тросической ниши по формуле Аевинса (Krebs, 1990):

$$
\mathrm{B}=\left(\sum \mathrm{p}_{\mathrm{i}}^{2}\right)^{-1},
$$

гле $p_{i}-$ Аоля кормовой категории в питании вида.
The main role in the diet of large birds of prey in Vitebsk Region plays small mammals, birds, reptiles and tailless amphibians (Anura).

The group of large birds of prey under study includes both focused specialists (ornithophagous Goshawk and herpetophagous Short-Toed Eagle) and generalists (polyphagous Greater and Spotted Eagles). The intermediate position in this row is occupied by the Golden Eagle (Aquila chrysaetos), whose diet consists of mammals and birds in almost equal parts.

During the breeding season mammals (especially small- and medium-sized) are the main part of the diet of large birds of prey. Polyphagous species (Spotted Eagles) has the widest trophic niche (fig.1).

To analyze the adaptive mechanisms of distributing trophic sources between the raptors species during the breeding season we made a dendrogram of trophic niche overlapping between species (table 2, fig. 2). The dendrogram built according to Brey-Curtis method
Самка ястреба-тетеревятника (Accipiter gentilis) на гнезде с птенцами (вверху слева), самка малого подорлика (Aquila [Clanga] pomarina) кормит птенца (вверху справа) и взрослый змееял (Circaetus gallicus) и птенец с $\Delta$ Oбычей в гнезде (внизу). Фото $\Delta . И$. Шамовича и B.М. Фецосенко.

Female Northern Goshawk (Accipiter gentilis) with nestlings in the nest (top left); female Lesser Spotted Eagle (Aquila [Clanga] pomarina) feeding her nestling (top right); adult Short-toed Eagle (Circaetus gallicus) and a nestling with prey in a nest (at the bottom). Photos by D.I. Shamovich and V.M. Fedosenko.

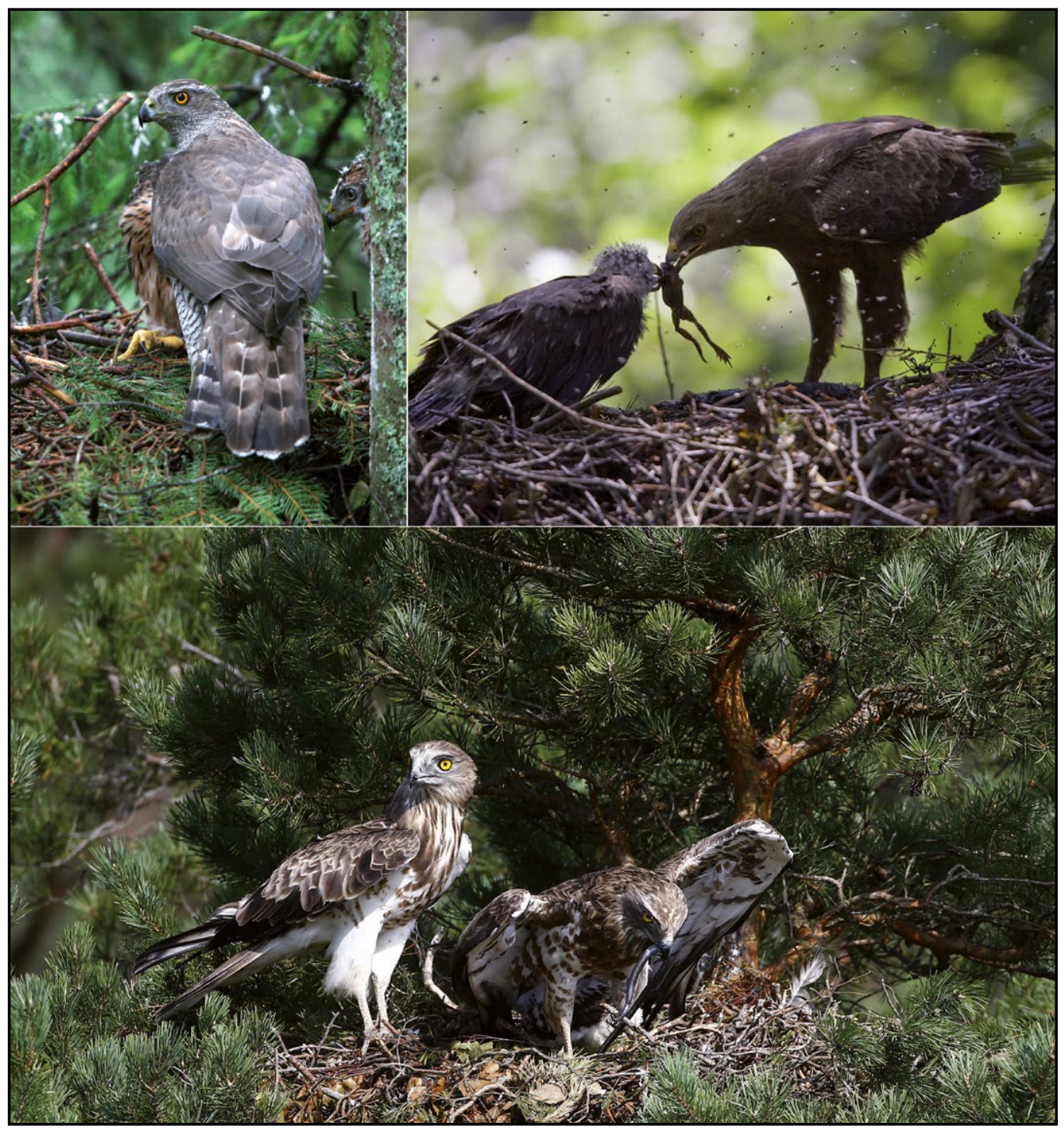


Беркут с Аобытым зайцем-беляком (Lepus timidus). Фото С.М. Плыткевича.

Golden Eagle with prey (Hare Lepus timidus). Photo by S.M. Plytkevich.

Аля выделения гильдий и нагляАного представления результатов был проведён киастерный анализ. Исходные данные мия построения деньрограмм представлены в виде симметричной матрицы перекрытия тросических ниш на основе индекса трофического сходства. Перекрытие тросических ниш рассчитывалось по формуле Мориситы - Хорна (Krebs, 1999):

$$
\mathrm{C}_{\mathrm{MH}}=\frac{2 \sum_{i}^{n} \mathrm{p}_{\mathrm{ij}} \mathrm{p}_{\mathrm{ik}}}{\sum_{i}^{n} \mathrm{p}^{2}{ }_{\mathrm{ij}}+\sum_{i}^{n} \mathrm{p}^{2} \mathrm{ik}},
$$

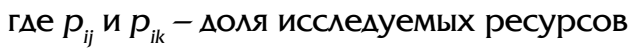
экологической ниши Аля Авух виАов. Значение $\mathrm{C}_{\text {мн }} \geq 0,6$ считалось экологически и статистически значимым.

В качестве статистических тестов использоваяи следуюшие: G-критерий максимального правдоподобия мия сравнения процентов или Аолей из различных пропорций и t-критерий Стьюдента м^я сравнения средних значений (Лакин, 1990; Песенко, 1982; Sokal, Rohlf, 1995). При проведении киастерного анамиза и построении Аендрограмм использовамись метрика Брея-Кёртиса и метрика Жаккара.

Статистические расчёты производикись на персонаиьном компьютере с использованием программ Microsoft Excel и PAST 3.06. Аия хранения, оперативной первичной информации и статистической обработки полученных манных использована проблемно ориентированная база данных коммективного пользования FEEDCARN.

\section{Результаты исследований и их обсуж- пение}

Настояшая публикация подводит итог многолетнему изучению тросической конкуренции межАу хишными птицами в лесоболотных комплексах Северной Беларуси. Под "лесоболотными комплексами" мы понимаем крупные по плошали комплексы, вкиючаюшие леса и болота различных типов в разных сочетаниях.

В результате исследований выявлены механизмы амаптаций, которые используют хишные птицы мия ослабления тросической конкуренции и разделения тросических ресурсов.

Исследования проведены на территории Витебской области Беларуси, которая

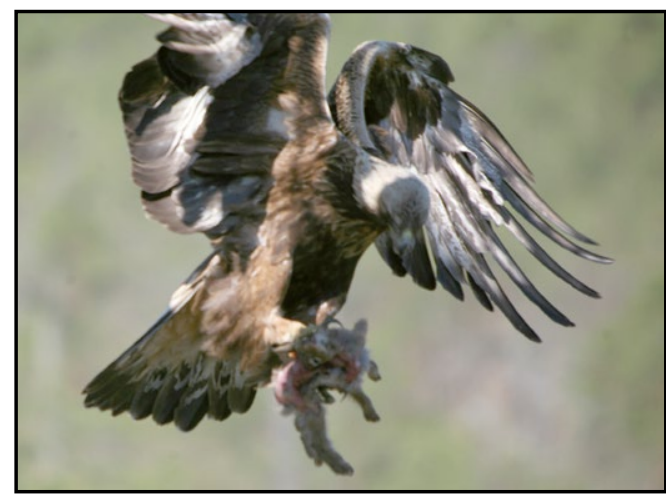

clearly divided species under study into two guilds. The first guild includes three species (the Golden Eagle, the Greater Spotted Eagle, and the Goshawk), the second guild includes two species (the Short-Toed Eagle and the Lesser Spotted Eagle). Table 2 revealed pairs of species that could compete for the main food resources, since they have a $C_{M H}$ index $\geq 0.6$ or close to this value (0.56, 0.58).

In the first guild, the Goshawk escapes from the competition with other species by preying predominantly in the forests, in contrast to the Golden Eagle (the main preying biotope - upland bogs) and the Greater Spotted Eagle (the main preying biotope lowland bogs and bottomland meadows).

The Short-Toed Eagle and the Lesser Spotted Eagle have insignificant overlapping of trophic niches - it is statistically and ecologically insignificant. They both share interests only for amphibians as a prey: in the diet of the Lesser Spotted Eagle amphibians make $25.5 \%$ of $C B$, and in the Short-Toed Eagle $14.4 \%$ of $C B$.

\section{Conclusions}

The obtained results bring us to the conclusion that during the nesting period in the forest-bog complexes of Northern Belarus, there are examples of both generalization and extreme specialization in diet among large birds of prey. Both Greater and Lesser Spotted Eagles are typical generalists, the Short-Toed Eagle and the Goshawk are specialists.

To reduce trophic competition large birds of prey most often use the following adaptation mechanisms:

- adaptation to certain hunting biotopes leads to a difference in prey (the Goshawk and other birds of prey, the Golden Eagle and Greater Spotted Eagle);

- adaptation to prey on different age categories of prey (for instance, the Golden Eagle prey mostly on adult hares, while the Greater Spotted Eagle - on leverets). 
Табл. 1. Питание (в \% ПБ) крупных хишных птиц в гнездовой период в лесоболотных комплексах (Белорусское Поозерье).

Table 1. Diet (in \% CB) of large birds of prey in the nesting period in forest-swamp complexes of the Belorussian Lakeland.

\begin{tabular}{|c|c|c|c|c|c|}
\hline Пища / Prey categories & $\begin{array}{r}\text { Aquila } \\
\text { chrysaetos }\end{array}$ & $\begin{array}{r}\begin{array}{r}\text { Aquila [Clanga] } \\
\text { clanga }\end{array} \\
\end{array}$ & $\begin{array}{r}\text { Aquila [Clanga] } \\
\text { pomarina } \\
\end{array}$ & $\begin{array}{r}\text { Circaetus } \\
\text { gallicus }\end{array}$ & $\begin{array}{r}\text { Accipiter } \\
\text { gentilis }\end{array}$ \\
\hline Аягушки / Frogs & & 3 & 25.5 & 14.4 & \\
\hline Жабы / Toads & & & 7.8 & & \\
\hline Ящерицы / Lizards & & 0.1 & 0.4 & 28.7 & \\
\hline Змеи / Snakes & & 3 & 8.1 & 51.9 & \\
\hline Землеройки / Shrews & & 0.3 & 0.3 & & \\
\hline Крот / Moles & 0.1 & 4 & 4.4 & & \\
\hline Водяная полёвка / Water Voles & 0.8 & 18.7 & 2.2 & & 0.1 \\
\hline Полёвки рода Microtus / Voles & 0.1 & 1.0 & 8.6 & 3.1 & \\
\hline Мыши рода Apodemus / Mice & & 0.3 & 0.8 & & 0.4 \\
\hline Рыжая полёвка / Bank Vole & & 0.5 & 1.2 & & \\
\hline Аругие мелкие грызуны / Other small rodent species & & 0.1 & 11.8 & & \\
\hline Белка, ондатра, ёж / Squirrel, Muskrat, Hedgehog & 2 & 18.7 & 15 & & 1.2 \\
\hline Зайцы / Hares & 40.1 & 40.7 & 0.7 & 1.9 & 4.4 \\
\hline Косуля / Roe Deer & 7.4 & & & & \\
\hline Аикий кабан / Wild Boar & 2.3 & & & & \\
\hline Ааска, горностай / Weasel, Stoat & 0.1 & 0.4 & 0.3 & & 0.2 \\
\hline $\begin{array}{l}\text { Норки, хорёк, лесная куница } \\
\text { Minks, Polecat, Pine Marten }\end{array}$ & 2.6 & 2.9 & 3.1 & & 0.9 \\
\hline $\begin{array}{l}\text { Аисица, енотовидная собака, барсук } \\
\text { Red Fox, Raccoon Dog, Badger }\end{array}$ & 1.8 & & & & \\
\hline Аомашние животные / Domestic animals & 0.4 & & & & \\
\hline Пахаиь / Carrion & 7.6 & & & & \\
\hline Мелкие птицы до Арозда / Small sized birds & 2.2 & 2.2 & 6 & & 5.9 \\
\hline Птицы крупнее дрозда / Medium sized birds & 32.5 & 4.1 & 3.8 & & 86.9 \\
\hline Ширина ниши / Trophic niche width & 2.65 & 4.0 & 5.52 & 1.49 & 1.31 \\
\hline
\end{tabular}

имеет плошаць 40,1 тыс. кв. км и исторически носит название Белорусского Поозерья. Аеса составляют от обшей плошали области около 34\%. Болота области представлены тремя типами (низинные, переходные и верховые) и занимают около $9 \%$ территории.

В лесоболотных комплексах постоянно охотятся 5 виАов крупных хишных птиц, а именно: ястреб-тетеревятник (Accipiter gentilis), большой подорлик (Aquila [Clanga] clanga), мамый подормик (Aquila [Clanga] pomarina), беркут (Aquila chrysaetos), змееял (Circaetus gallicus) (ФеАюшин, Аолбик, 1967; Ивановский, 2012).

Состав питания этих хишных птиц преАставлен в таблице 1 .
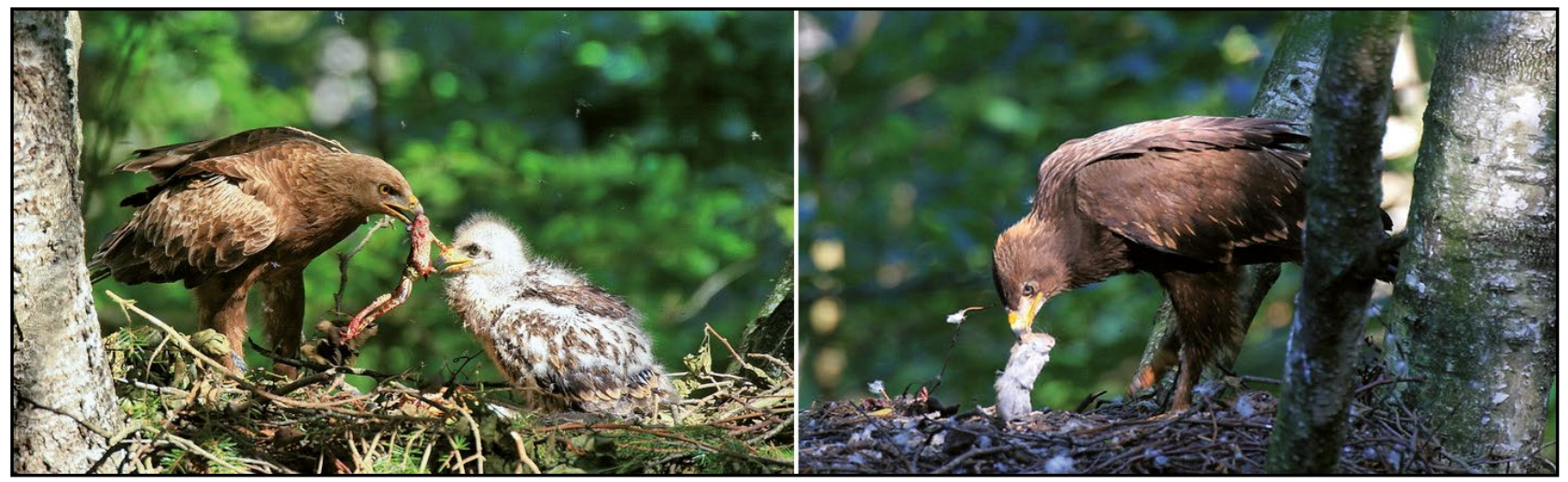

Взросый мамый подорлик принёс птенцу травяную мягушку (Rana temporaria) - слева и молодой маиый подорлик поеАает обыкновенную полёвку (Microtus arvalis) - справа. Фото В.И. Козловского.

Adult Lesser Spotted Eagle bringing a Common Frog (Rana temporaria) to his youngster - on the left; juvenile Lesser Spotted Eagle eating a Common Vole (Microtus arvalis) - on the right. Photos by V.I. Kozlovskiy. 


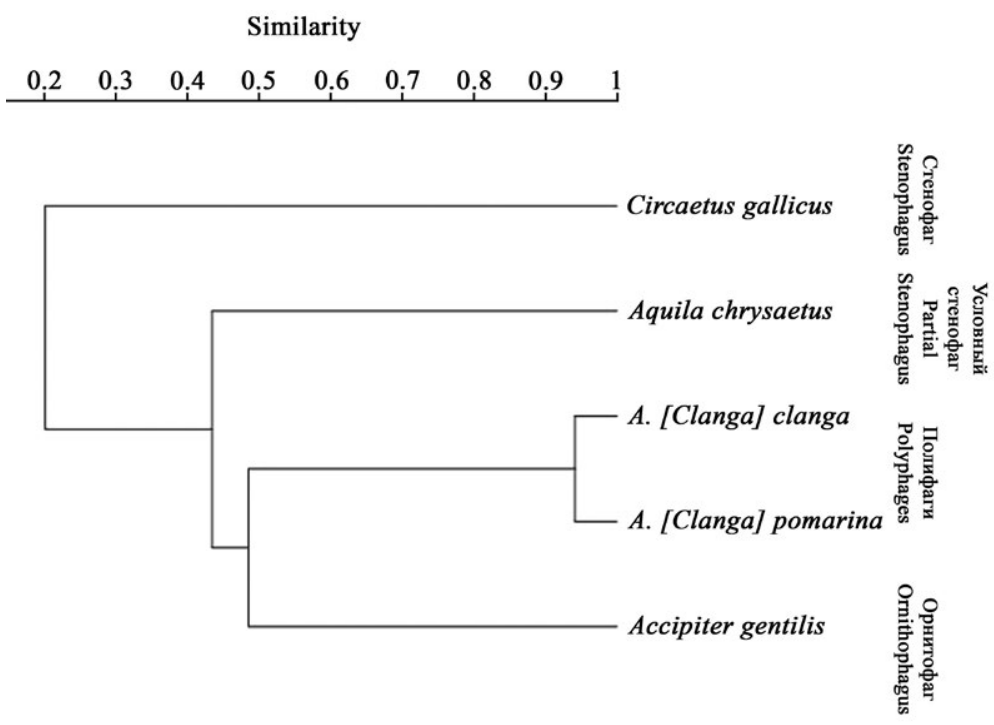

Pис. 1. Аендрограмма разбиения крупных хищных птиц на группы тросических специалистов в лесоболотном комплексе в гнездовой период.

Fig. 1. A dendrogram separating large species of raptors into guilds according to their food specialization.

Табл. 2. Перекрытие трофических ниш крупных хишных птиц в гнездовой период в лесоболотных комплексах (Белорусское Поозерье).

Table 2. Overlapping of trophic niches of large species of birds of prey during the nesting period in forest-swamp complexes of the Belorussian Lakeland.

\begin{tabular}{|c|c|c|c|c|c|}
\hline $\begin{array}{l}\text { ВИАЫ / } \\
\text { SPECIES } \\
\end{array}$ & $\begin{array}{r}\text { Aquila } \\
\text { chrysaetos } \\
\end{array}$ & $\begin{array}{r}\text { Aquila } \\
\text { [Clanga] } \\
\text { clanga } \\
\end{array}$ & $\begin{array}{r}\text { Aquila } \\
\text { [Clanga] } \\
\text { pomarina }\end{array}$ & $\begin{array}{r}\text { Circaetus } \\
\text { gallicus } \\
\end{array}$ & $\begin{array}{r}\text { Accipiter } \\
\text { gentilis }\end{array}$ \\
\hline $\begin{array}{l}\text { Aquila } \\
\text { chrysae- } \\
\text { tos }\end{array}$ & 1 & 0.7 & 0.1 & 0.02 & 0.58 \\
\hline $\begin{array}{l}\text { Aquila } \\
\text { [Clanga] } \\
\text { clanga }\end{array}$ & 0.7 & 1 & 0.56 & 0.09 & 0.11 \\
\hline $\begin{array}{l}\text { Aquila } \\
\text { [Clanga] } \\
\text { pomarina }\end{array}$ & 0.1 & 0.56 & 1 & 0.34 & 0.14 \\
\hline $\begin{array}{l}\text { Circaetus } \\
\text { gallicus }\end{array}$ & 0.02 & 0.09 & 0.34 & 1 & 0 \\
\hline $\begin{array}{l}\text { Accipiter } \\
\text { gentilis }\end{array}$ & 0.58 & 0.11 & 0.14 & 0 & 1 \\
\hline
\end{tabular}

Similarity

$\begin{array}{llllllllll}0.24 & 0.32 & 0.40 & 0.48 & 0.56 & 0.64 & 0.72 & 0.80 & 0.88 & 0.96\end{array}$

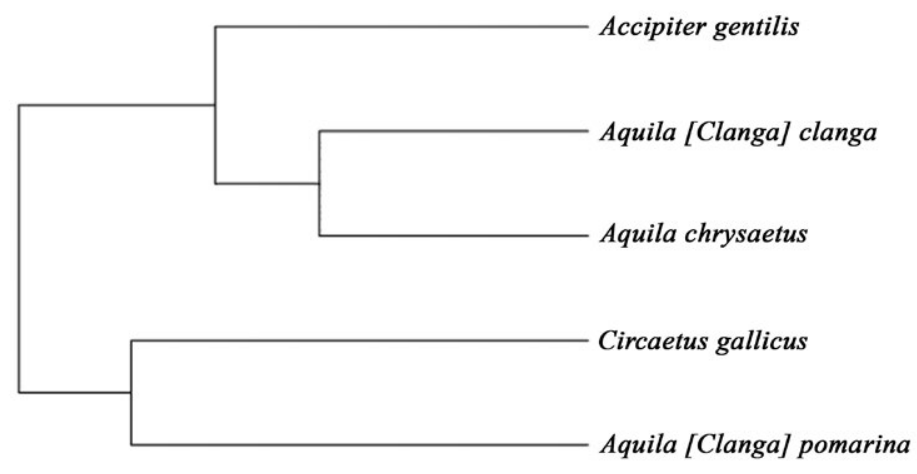

Наибольшее значение в питании крупных хишных птиц Белорусского Поозерья имеют млекопитаюшие, птицы, пресмыкаюшиеся и бесхвостые амсиибии.

Анамиз таблицы 1 показывает, что группа крупных хишных птиц, анаиизируемая нами, представлена полным спектром, от узких специалистов (орнитосраг - тетеревятник и герпетофраг - змееял) до генералистов (полисраги - мамый и большой подорлики). Промежуточное положение в этом ряну занимает беркут, основу питания которого составляют почти поровну млекопитаюшие и птицы.

В гнездовой период ммекопитаюшие, особенно мелкие и средние, являются наиболее важным тросическим ресурсом мля ряла крупных хишных птиц. Группа явных полифагов (подорлики) характеризуется наиболее широкими значениями ширины тросической ниши.

Продемонстрируем это, построив специальную цендрограмму, используя метрику Жаккара, которая позволяет, исходя из трофических связей, разбить наш список на группы относительных специалистов (рис. 1).

Таким образом, мы видим, что среди крупных хишных птиц имеются примеры как генераяизации, так и специализации в кормодобывании.

Аля проведения анамиза амаптивных механизмов разделения тросических ресурсов между крупными хишными птицами в гнездовой период в лесоболотных комплексах построим дендрограмму перекрытия тросических ниш (в \% ПБ), используя таблицу 2.

$\triangle$ ендрограмма, построенная по методу Брея-Кёртиса, (рис. 2) разбила анаиизи-

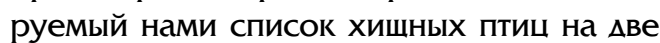
гильдии. Согласно таблице 2, у некоторых пар хишных птиц возможна конкуренция за основные пишевые ресурсы, так как $\mathrm{C}_{\mathrm{MH}} \geq 0,6$ или близок к этой цифре $(0,56$; 0,58). Первая гильдия вкиючает три вида (беркут, большой подорлик и тетеревятник). Вторая гильдия вкАючает два вида (змееял и мамый подорлик). Наша замача состоит в том, чтобы выяснить, в результа-

Рис. 2. Аендрограмма перекрытия трофических ниш (в \% ПБ) крупных хишных птиц в лесоболотных комплексах в гнездовой период.

Fig. 2. Dendrogram of overlapping of trophic niches of large birds of prey during the nesting period in forestswamp complexes of the Belorussian Lakeland. 
Птенец беркута (Aquila

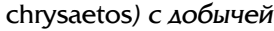
- четырьмя молодых куницами (Martes martes) - вверху слева, добыча в гнезде беркута - большой кроншнеп (Numenius arquata), средний кроншнеп (N. phaeopus), большой веретенник (Limosa limosa) и тетерев (Tetrao tetrix) - вверху справа, птенец беркута с остатками ворона (Corvus corax) - внизу. Фото В.В. Ивановского и В.А. Пушкина.

Nestling of the Golden Eagle (Aquila chrysaetos) and four dead young Pine Martens (Martes martes) as a prey (top left); prey from the Golden Eagle's nest - Eurasian Curlew (Numenius arquata), Whimbrel (N. phaeopus), Blacktailed Godwit (Limosa limosa) and Black Grouse (Tetrao tetrix) (top right); nestling of Golden Eagle with Raven's (Corvus corax) remains (at the bottom) Photos by V.V. Ivanovskiy and V.A. Pushkin.
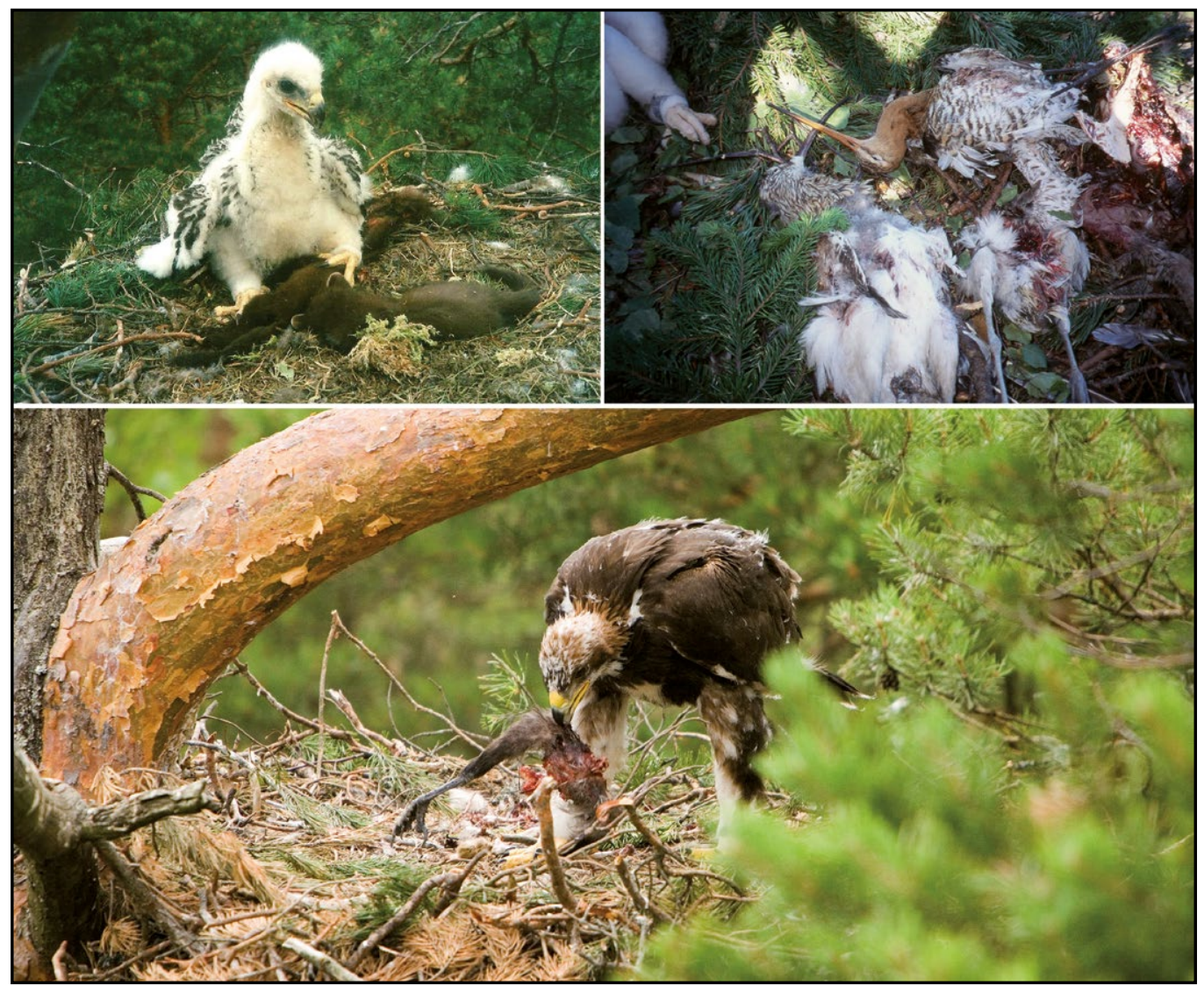

те каких компромиссов эти виды снижают тросическую конкуренцию.

В первой гильАии тетеревятник ограхил себя от конкуренции тем, что охотится в подавляюшем большинстве случаев в лесу, в отличии от беркута (основной охотничий биотоп - верховые болота) и большого подорлика (основной охотничий биотоп - низинные болота и пойменные луга). Возникает вопрос, почему в одну гильдию попали беркут и большой подорлик, которые, во-первых, охотятся в разных биотопах, вовторых, среАний вес их добычи значительно различается. Почему расчётная программа компьютера определила их в одну гильдию? Обратимся к таблице 1 , в которой приведён спектр питания в \% ПБ этих хишников. И наши недоумения разрешаются. Оказывается, что всё дело в зайцах. В питании беркута зайцы (в основном, взрослые беляки LepuS timidus) составляют 40,1\% ПБ, а у большого подорлика зайцы (искючительно зайчата русака Lepus europaeus) составляют 40,7\% ПБ. Не стоит также забывать, что подорлики очень пластичны в плане трофических связей, у них самые широкие трофические ниши среАи рассматриваемых хишных птиц, а именно: 5,52 единицы у малого и 4,0 - у большого (табл. 1).

Подорлики Аовольно быстро могут изменять свою тросическую ориентацию при изменении относительного обилия основных пишевых ресурсов, что также уменьшает тросическую конкуренцию.

У змееяла и малого полорлика перекрытие тросических ниш незначительно, статистически и экологически незначимо. Их интересы пересекаются только при добыче земноводных: у малого подорлика они составляют в питании 25,5\% ПБ, у змееяла - 14,4\% ПБ (табл. 1).

Несмотря на то, что амфибии (в основном, мягушки) регулярно регистрируются в питании некоторых видов крупных хишных птиц, можно констатировать, что среАИ хишных птиц Аишь маиый подорлик является относительно специализированным на их мобыче.

\section{ВЫвоАЫ}

Полученные результаты позволяют слелать вывод, что в гнездовой период в лесоболотных комплексах Северной Беларуси среди крупных хишных птиц имеются примеры как генерализации, так и крайней специамизации в кормодобывании. Типичными генералистами являются оба вида подорликов, среди специаиистов следует отметить змееяла и ястреба-тетеревятника.

Аля ослабления тросической конкуренции крупные хишные птицы чаше всего применяют следуюшие ахаптации: 
- адаптация к определённым охотничьим биотопам приводит к различию Аобычи (тетеревятник и Аругие хишники);

- адаптация к питанию не только разными видами, но и разными возрастными категориями жертв (беркут и большой поАорлик при добыче зайцев).

Резюмируя всё вышеизложенное, следует констатировать, что, в результате исторической парамельной эволюции, крупные хишные птицы смогли рационально "Скомпоновать" и "Встроить" свои тросические ниши в многовидовое сообшество крупных лесоболотных комплексов.

\section{Митература}

Ивановский В.В. Хишные птицы Белорусского Поозерья: монограсрия. Витебск: УО «ВГУ им. П.М. Машерова", 2012. 209 с. [Ivanovski V.V. The Birds of Prey in the Belorussian Poozerie. Vitebsk, 2012: 1-209. (in Russian).] URL: http:// rrrcn.ru/ru/archives/24498 Аата обрашения: 20.11.2018.

Ивановский В.В., Сидорович В.Е., Сидорович А.А. Механизмы разделения трофических ресурсов в открытых биотопах между хишными птицами и их конкурентами в гнездовой период на территории Беларуси. - Вестник Чувашского государственного педагогического университета им. И.Я. Яковлева. 2018. № 2(98). - С. 33-42. [Ivanovsky V.V., Sidorovich V.E., Sidorovich A.A. Mechanisms of trophic resources partitioning between birds of prey and their competitors in open habitats during nesting period in Belarus. - I. Yakovlev Chuvash State Pedagogical University Bulletin. 2018. 2(98): 33-42. (in Russian).] URL: http://vestnik.chgpu.edu. $\mathrm{ru} /$ ?do=archive\& vid=2\& nom=737 $\triangle$ ата обрашения: 20.11.2018.

Иакин Г.Ф. Биометрия. Издание 4-е, переработанное и дополненное. М.: Высшая школа, 1990. 351 c. [Lakin G.F. Biometrics. $4^{\text {th }}$ edition, revised and enlarged. Moscow, 1990: 1-351. (in Russian).]

Песенко Ю.А. Принципы и методы количественного анаяиза в фаунистических исследованиях. М.: Наука, 1982. 286 с. [Pesenko Yu.A. Principles and methods of quantitative analysis in faunistic studies. Moscow, 1982: 1-286. (in Russian).]

Сидорович А.А. Методология исследования позвоночных хишников: изучение питания. Учебно-методическое пособие. Минск: БГУ, 2014. 88 c. [Sidorovich A.A. The methodology of the study of vertebrate predators: the study of nutrition. Teaching manual. Minsk, 2014: 1-88. (in Russian).]

Федюшин А.В., Аолбик М.С. Птицы Белоруссии. Минск: Наука и техника, 1967. 520 с. [Fedyushin A.V., Dolbik M.S. Birds of Belarus. Minsk. 1967: 1-520. (in Russian).]
Шепель А.И., Маяков А.А. Вицоспецисрические признаки костей таза, голени и белра некоторых млекопитаюших. - IV съезд Всесоюзного териологического общества: тезисы цокиацов. Т. 1. М., 1986. С. 105. [Shepel A.I., Mayakov A.A. Species-specific signs of the bones of the pelvis, lower leg and thigh of some mammals. - IV Congress of the All-Union Theriological Society: Abstracts. Vol. 1. Moscow, 1986: 105. (in Russian).]

Шепель А.И., Шохрин В.А. Реконструкция размера и веса обыкновенных полёвок из погацок пернатых хишников. - Регионамьные проблемы экологии: Тезисы Аокиацов конференции экологов Волжско-Камского края. Казань, 1985. C. 132. [Shepel A.I., Shokhrin V.A. Reconstruction of the size and weight of common voles from the pellets of feathered predators. - Regional problems of ecology: Abstracts of the conference of environmentalists of the Volga-Kama region. Kazan, 1985: 132. (in Russian).]

Böhme G. Zur Bestimmung quartärer Anuren Europas an Hand von Skelettelementen. - Wissenschaftliche Zeitschrift der Humboldt-Universitat zu Berlin. 1977. 26(3): 283-300.

Brown R., Ferguson J., Lees D. Tracks and Signs of the Birds of Britain and Europe. London: Christopher Helm Publishers Ltd, 1999: 1-232.

Jedrzejewska B., Jedrzejewski W. Predation in Vertebrate Communities. The Bialowieza Primeval Forest as a Case Study. Berlin: Springer, 1998: 1-450.

Krebs J.K. Ecological Methodology. $2^{\text {nd }}$ Ed. Oslo: Addison - Welsey Longman, Inc., 1999: 1-620.

Marti C.D., Steenhof K., Kochert M.N. \& Marks J.S. Community trophic structure: the roles of diet, body size, and activity time in vertebrate predators. - Oikos, 1993. 67(1): 6-18. DOI: 10.2307/3545090 URL: https://www.jstor.org/ stable/3545090 Аата обрашения: 20.11.2018.

März R. Prey Remnants in Pellets and ScatsofPredators. Berlin: Akademie Verlag, 1987: 1-288.

März R. Gewöll - und Rundfunkskunde. XIII. Berlin: Akad. Verlag, 1972: 1-288.

Newton I. Population Ecology of Raptors. London: T\&A D Poyser Ltd., 1979: 1-399.

Newton I. Population limitation in diurnal raptors. - Canadian Field-Naturalist, 1976. 90(3): 274-300.

Pucek Zd. Keys to Vertebrates of Poland Mammals. Warsaw: Polish Scientific Publishers, 1981: 1-367.

Sidorovich V.E. Analysis of vertebrate predator - prey community. Minsk: Tesey, 2011: 1-736.

Sokal R.R., Rohlf F.J. Biometry. $4^{\text {th }}$ ed. N.Y.: W.H. Freeman, 2011 : 1-937.

Teerink B.J. Hair of West - European Mammals. Cambridge: Cambridge University Press, 1991: 1-224. 